\title{
Milksolids production from cows grazing timothy/white clover in comparison with ryegrass pastures
}

\author{
N. A. THOMSON and J.K. KAY \\ Dexcel, PB 3221, Hamilton \\ norman.thomson@dexcel.co.nz
}

\begin{abstract}
Three experiments were conducted to compare milksolids (MS) production from cows grazing similar herbage allowances of timothy (Phleum pratense)/white clover (Trifolium repens) and perennial ryegrass (Lolium spp.) pastures. Two experiments were shortterm ( 2 weeks), one in spring 2000 (Experiment 1) and one in autumn 2001 (Experiment 2), and one longerterm (12 weeks) irrigated trial in summer/autumn 2002 (Experiment 3). In Experiment 1, the yield of all milk components; fat, protein, MS, casein and lactose, was greater from timothy/white clover than ryegrass, whereas in Experiment 2, the production of these components from timothy/white clover was less than from ryegrass. The protein content of timothy/white clover was greater than ryegrass in spring $(\mathrm{P}<0.05)$ but similar in autumn. In spring, acid detergent fibre (ADF) and neutral detergent fibre (NDF) were similar but in autumn they tended to be higher in timothy/white clover than ryegrass, indicating poorer quality of timothy/white clover relative to ryegrass in autumn. In spring and autumn the digestibility and metabolisable energy (ME) of the two pastures types were similar. In Experiment 3 the pastures were irrigated. The experiment was a crossover design with the cows grazing each of the timothy/white clover and ryegrass pastures for two, three-week periods. The yield of all milk components was greater from Timothy/white clover than ryegrass. Digestibility and ME were similar for the two pastures but the timothy/white clover pastures had lower NDF and higher water-soluble sugar content than ryegrass. More cows were carried on the timothy/white clover pasture and as a result MS production/ha was increased by $30 \%$. This research identifies an opportunity for greater use of irrigated timothy/white clover pasture in dairying systems not subjected to an Argentine Stem Weevil (ASW) challenge.
\end{abstract}

Keywords: milksolids production, nutrient composition, perennial ryegrass, timothy, white clover

\section{Introduction}

There is a general lack of information available on animal performance from grazing timothy (Phleum pratense) pastures particularly in comparison with ryegrass (Lolium spp.) pastures. Timothy is the dominant pasture species in Northern Europe and Canada (Havstad \& Aamlid 2001) but is used there almost solely for hay production. Timothy is described as palatable, cold tolerant, late heading, suitable for making hay and is generally considered to lack persistency under grazing (Caradus 1988). Timothy has not been recommended as a pasture species for dairying in the North Island, New Zealand because of its susceptibility to ASW, Listronotus bonariensis (Barker 1989). However, for the South Island where ASW is not as prevalent, timothy is recommended in pasture mixes to improve production of high quality pasture (Thom et al. 2001).

In the South Island of NZ, Lewis \& Cullen (1972) reported superior lamb growth post-weaning on timothy/cocksfoot compared to ryegrass pastures. Scott \& Maunsell (1981) also in the South Island showed in a four-year study that timothy under irrigation and high fertiliser inputs exhibited higher annual dry matter (DM) production $(14.5 \mathrm{t} / \mathrm{ha})$ than perennial ryegrass $(10.1 \mathrm{t} /$ ha). Caradus (1988) reported under North Island conditions that grazed timothy (cv. Kahu) persisted for at least 7 years. More recently, Maunsell \& Scott (1996) report that timothy produced as well as perennial ryegrass in dryland and irrigated conditions. An interesting observation made by these authors was that "timothy increased in performance over the four years" of the trial. These studies demonstrate that under grazing, especially in the South Island of NZ, timothy is productive, reasonably persistent and possibly superior to ryegrass as a lamb finishing pasture. A series of trials conducted on the Taranaki Agricultural Research Station (TARS) in South Taranaki (Johnston \& Thomson 1996) report that milk and milk fat yield was greater from cows grazing pure swards of timothy than perennial ryegrass. In practice, timothy would be sown with white clover and as an extension of the work in Taranaki, a programme was established at Dexcel in 2000 to investigate whether MS production could be improved by the incorporation of timothy/white clover pastures into a dairy system.

\section{Materials and methods}

In autumn (April) 2000, a 2.25 ha block (old timothy pasture) was established into timothy (cv. Kahu) and white clover (Trifolium repens, cv. Aran \& cv. Sustain) on the Dexcel No 5 Dairy. In autumn (May) 2001 a further 3 ha was established (new timothy pasture) into timothy (cv. Charlton) and the same white clover 
cultivars. The sowing rates were $6 \mathrm{~kg} /$ ha for timothy and $4 \mathrm{~kg} / \mathrm{ha}$ for white clover $(2 \mathrm{~kg} / \mathrm{ha}$ of each Aran and Sustain). Establishment of the initial 2.25 ha was satisfactory but the establishment of the second area was considered poor with the proportion of timothy being assessed as less than $20 \%$. In spring (September) 2001 the "new" area of timothy/white clover pasture was re-established. Paddocks for the ryegrass comparison were selected from the area established into Yatsyn ryegrass in March 1992 for the experimental work reported by Thom et al. (1999). These paddocks were able to be irrigated and contained a high proportion of perennial ryegrass $(>80 \%)$ but minimal white clover $(<5 \%)$.

Three experiments were conducted during 2000 to 2002. The first two experiments were run to determine over the short-term (two weeks) whether there was an effect of pasture species on milk yield and composition. Ten Holstein/Friesian cows were allocated to each treatment, balanced for live weight, MS yield, and lactation days. The selected cows were grazed as one herd in a two-week preliminary period on ryegrass pastures prior to being split into two treatments for the two-week experimental period. Experiment 1 was conducted in spring (7-21 November 2000) and Experiment 2 in autumn (13-27 March 2001). The cows used in these two experiments were $84 \pm 17$ days in milk and $223 \pm 18$ days in milk for Experiments 1 and 2, respectively. The summer of 2000/2001 was dry and after the first week of Experiment 2, cow numbers were reduced to eight/treatment to maintain an ad libitum pasture allowance. In each experiment the cows grazed on 20 days regrowth.

Experiment 3 ran from 9 Jan uary to 3 Apr il 2002. This experiment comprised four, three-week periods and after each three weeks the 16 Holstein/Friesian cows $(162 \pm 19$ days in milk at the start of the experiment) in each treatment were crossed-over to the alternate pasture type. Additional cows were added to either trea tment if the herbage allowance exceeded $45 \mathrm{~kg} \mathrm{DM} / \mathrm{cow} / \mathrm{d}$ or, the residual pasture exceeded a rising plate meter reading of 10 (approximately $2200 \mathrm{~kg} \mathrm{DM} / \mathrm{ha}$ ). If the herbage allowance or residual herbage mass was less than these targets, added cows were removed until the herbage allowance and residual herbage mass targets were achieved. The 32 experimental cows (16 per treatment) remained for the duration of the experiment. Both pastures were spray irrigated ( $40 \mathrm{~mm}$ each irrigation) on an approximate two-week cycle. Nitrogen $(\mathrm{N})$ fertiliser $(20 \mathrm{~kg} / \mathrm{ha})$ was applied to all paddocks before the experiment commenced and mid-way through the 12week experimental period.

When grazing the timothy/white clover pasture the 21-day rotation started in the "new" block for 12 days followed by the "old" block for the last nine days. The first two weeks of each three-week period was considered a pre-conditioning period. The average milk yield and composition recorded during week three, while cows were grazing the "old" block of timothy/white clover pasture, was used to compare the effects of pasture type on dairy cow performance.

\section{Trial design and management}

The protocols for taking measurements on the three experiments were similar. In Experiments 1 and 2, information on dairy cow productivity; live weight, body condition score (BCS), milk yield and milk composition was collected during the second week of the preliminary period and the information was used as a covariate to minimise variance in the comparisons made at the end of the experiment. Experiment 3 was a crossover design, so collection of data during a preliminary period was not needed.

\section{Measurements \\ Milk yield and composition}

For Experiments 1 and 2, milk yield and milk composition was recorded on each cow at the end of the preliminary period and twice weekly during the two weeks of the experimental period. In Experiment 3 milk yield and composition was recorded on only the experimental cows twice during week three of each experimental period. Milk yields were determined using in-line milk meters (Tru Test, Palmerston North, NZ). The afternoon and morning milk sample was bulked then analysed for fat, crude protein (CP), casein, lactose, and total solids concentration using a MilkoScan FT 120 (FOSS, Hillerød, Denmark) milk analyser. Additional milk samples were also analysed by reference procedures to correct the FT 120 results for matrix effects associated with treatment and stage of lactation (Fat: Roëse Gottlieb method, International Dairy Federation 1987, Total N: by macro-Kjeldahl digestion, Barbano et al. 1991).

\section{Cow live weight and body condition score}

For two consecutive days at the end of the preliminary (Experiments 1 and 2) and at the end of each experimental period (Experiments 1,2 and 3) the cows were weighed and BCS recorded. The average live weight and BCS for the two consecutive days was used to determine pasture species effects on live weight, $\mathrm{BCS}$, liveweight change, and BCS change.

\section{Pasture herbage mass assessment}

On Monday, Wednesday and Friday of each week of Experiment 1 and 3 only, herbage mass was assessed on the last 2 paddocks grazed and on the next 2 paddocks to 
Table 1 Effect of cows grazing ryegrass and timothy pastures in Experiment 1 ( $84 \pm 17$ days in milk), Experiment 2 (223 \pm 18 days in milk) and Experiment 3 (162 \pm 19 days in milk) on liveweight change, BCS change, milk yield, milk composition and milk component yield.

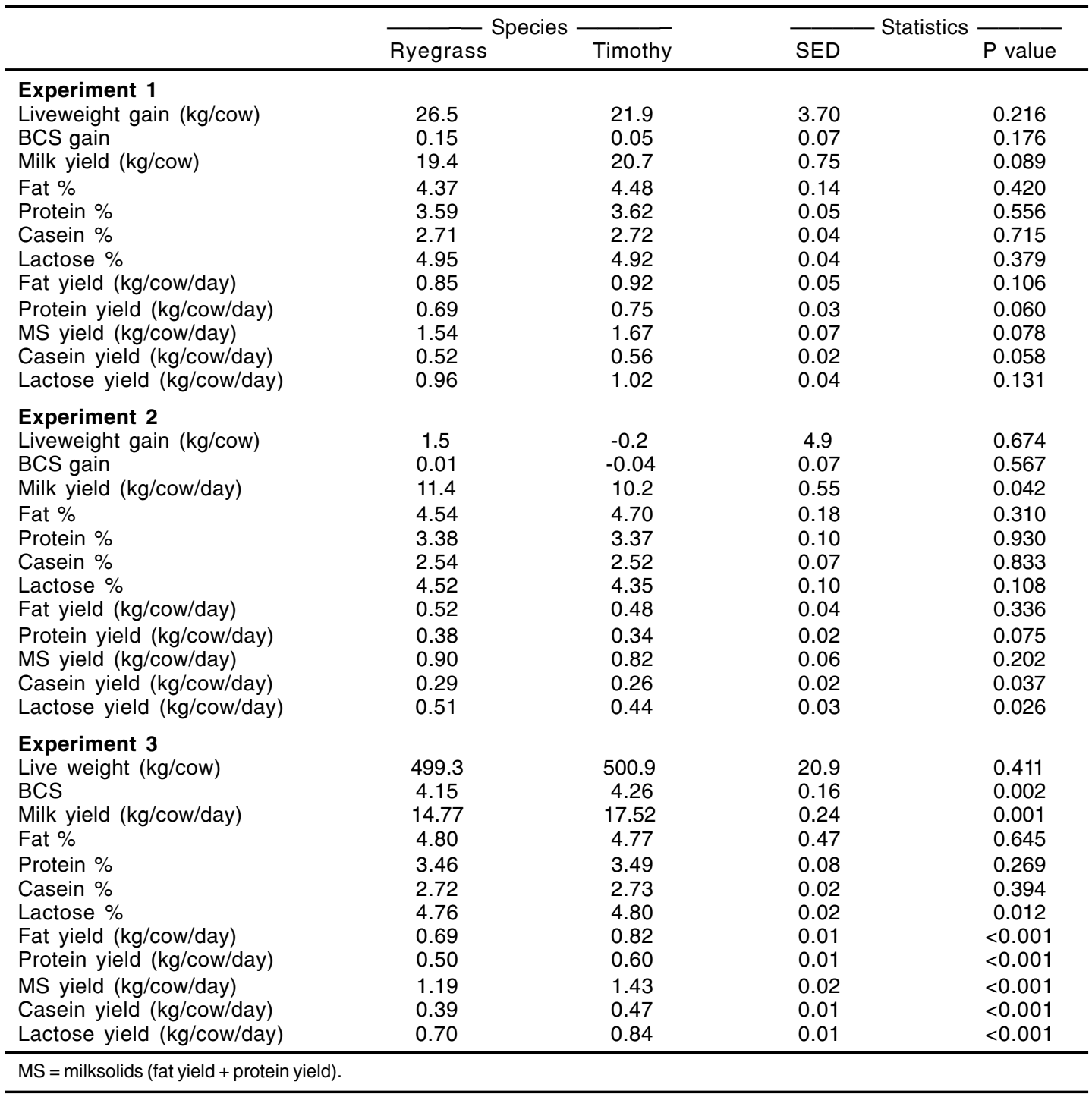

be grazed using a rising plate meter with electronic counter (Farmworks, Palmerston North, NZ). On average, 80 meter readings were recorded for each paddock and from the average plate meter reading, herbage mass was determined using daily equations (Thomson et al. 2001). The same equations were used for ryegrass and timothy pasture and no calibration for pasture species was undertaken.

\section{Pasture botanical and chemical composition}

On three occasions each week (Monday, Wednesday and Friday), a pasture sample was collected from each of the next two paddocks to be grazed (Experiments 1, 2 and 3) by taking approximately 30 random pasture samples/paddock by cutting $70 \times 500 \mathrm{~mm}$ strips to grazing height. The two samples for each pasture type were mixed and split into either one or two sub-samples. One sample (Experiments 1, 2 and 3) was oven-dried and bulked weekly for CP, NDF, ADF, digestible organic matter (DOM), water soluble sugars (WSS), and ME analyses by near infrared spectrometry (NIR) technology (FeedTECH, Palmerston North). The second sample collected (Experiment 3 only) was dissected into the botanical components; ryegrass, timothy, other grasses, clovers, dead material and weeds. 
Table 2 The nutrient composition (\% of DM) of timothy/white clover (Timothy) and ryegrass pastures in Experiment 1 (7-21 November 2000), Experiment 2 (13-27 April 2001), and Experiment 3 (9 January 3 April 2002).

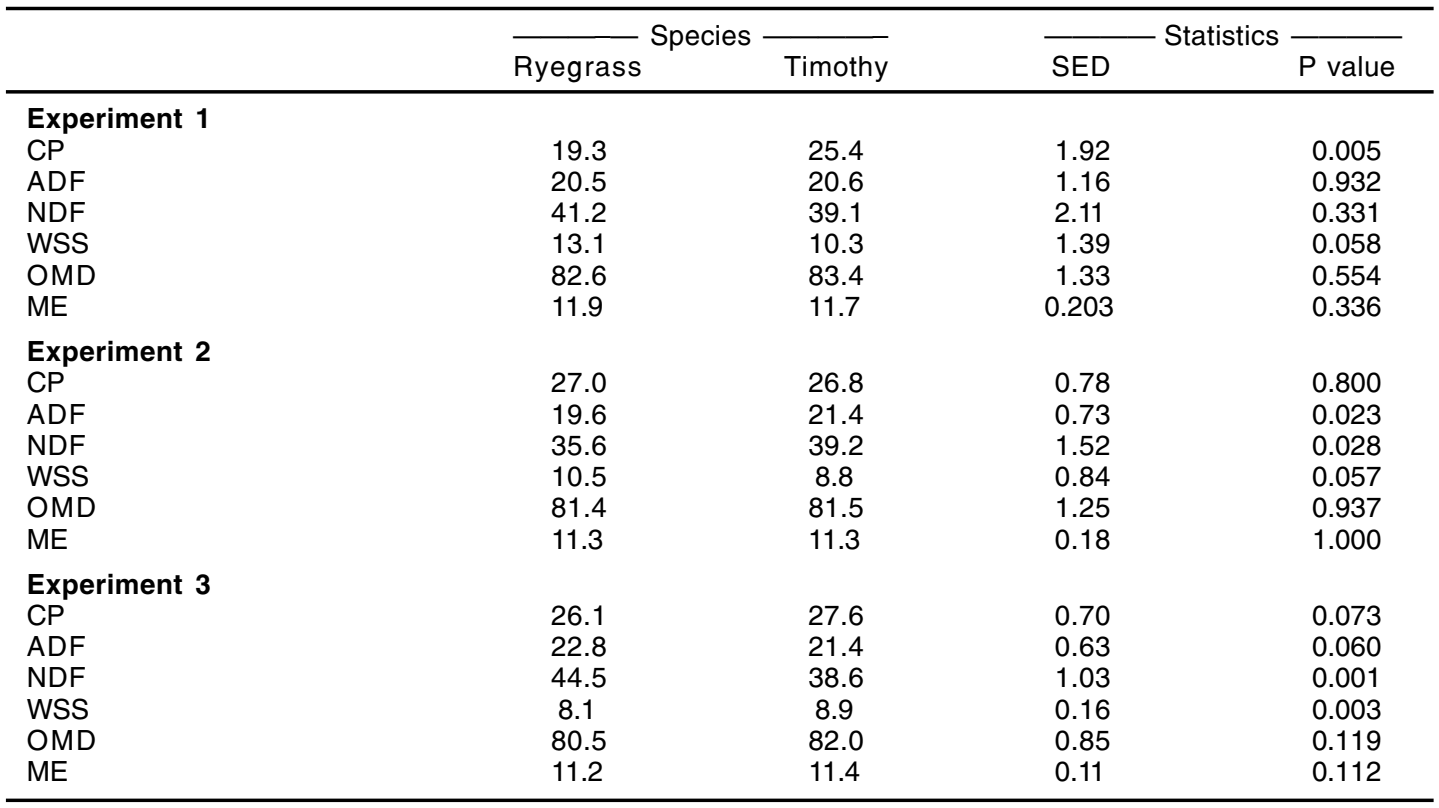

Table 3 Pre- and post-grazing herbage mass and DM intake recorded from timothy/white clover (Timothy) and ryegrass pastures during spring 2000 (Experiment 1), autumn 2001 (Experiment 2) and summer/ autumn 2002 (Experiment 3).

\begin{tabular}{|c|c|c|c|c|}
\hline & Ryegrass & Timothy & SED & $P$ value \\
\hline \multicolumn{5}{|l|}{ Experiment 1} \\
\hline Pre-graze (kg DM/ha) & 3220 & 3300 & 280 & 0.778 \\
\hline Allowance (kg DM/cow/day) & 48.3 & 49.5 & 4.4 & 0.788 \\
\hline Post-graze (kg DM/ha) & 2300 & 2340 & 150 & 0.792 \\
\hline $\begin{array}{l}\text { Rate of DM disappearance } \\
(\mathrm{kg} \mathrm{DM} / \mathrm{cow} / \mathrm{day})\end{array}$ & 13.7 & 14.3 & 2.5 & 0.813 \\
\hline $\begin{array}{l}\text { Intake (alkane) } \\
\text { (kg DM/cow/day) }\end{array}$ & 16.9 & 23.1 & 1.20 & $<0.001$ \\
\hline \multicolumn{5}{|l|}{ Experiment 2} \\
\hline $\begin{array}{l}\text { Intake (alkane) } \\
\quad \text { (kg DM/cow/day) }\end{array}$ & 10.2 & 12.1 & 0.87 & 0.043 \\
\hline \multicolumn{5}{|l|}{ Experiment 3} \\
\hline Pre-graze (kg DM/ha) & 3490 & 3600 & 64 & 0.091 \\
\hline Post-graze (kg DM/ha) & 2480 & 2370 & 42 & 0.009 \\
\hline Allowance (kg DM/cow/day) & 46 & 44 & 1.3 & 0.09 \\
\hline $\begin{array}{l}\text { Rate of DM disappearance } \\
(\mathrm{kg} \mathrm{DM} / \mathrm{cow} / \mathrm{d})\end{array}$ & 13.4 & 14.7 & - & - \\
\hline Intake (alkane) (kg DM/cow/day) & 13.0 & 11.1 & 0.87 & 0.036 \\
\hline
\end{tabular}

\section{Intake}

During the last five days of each experimental period pasture intakes were assessed by the alkane method (Dove \& Mayes 1991). For ten consecutive days an alkane capsule (C32:0) was administered before each morning and afternoon milking to 10 cows/treatment in Experiment 1, eight cows/treatment in Experiment 2 and 6 cows/treatment in Experiment 3. During the last five days of drenching, faecal samples were collected at the same time as capsules were being administered. The faecal samples taken from each cow during each period were bulked and a sub-sample oven dried at $65^{\circ} \mathrm{C}$ until the sample attained constant weight. The sub-sample was then ground for alkane analysis by gas chromatography. During the last five days of drenching, pasture samples were also collected (in triplicate) from 
Table 4 The average botanical composition (\% of DM) of irrigated timothy/white clover (Timothy) and ryegrass pastures recorded on the trial areas during summer and autumn 2002 (Experiment 3).

\begin{tabular}{lcccccc}
\hline & Ryegrass & Timothy & Clover & OGs & Weeds & Dead \\
\hline Ryegrass & 81.1 & - & 2.6 & 5.8 & 1.6 & 8.9 \\
SEM & 1.8 & - & 0.6 & 1.3 & 0.6 & 0.7 \\
Timothy "old" & - & 64.7 & 16.0 & 10.8 & 1.3 & 7.2 \\
SEM & - & 4.4 & 2.2 & 3.0 & 1.1 & 1.2 \\
\hline
\end{tabular}

$\mathrm{OG}=$ other grasses (these were mainly hybrid ryegrass $L$. boucheanum syn $L$. hybridium and prairie grass).

Table 5 Effect of pasture type on no of cows grazed, stocking rate and milksolids production (kg MS/ha/d) for the duration of the 12-week experiment (Experiment 3) conducted during summer and autumn 2002.

\begin{tabular}{|c|c|c|c|c|c|}
\hline & \multicolumn{2}{|c|}{ Species } & \multicolumn{2}{|c|}{ Statistics } & \multirow{2}{*}{$\begin{array}{l}\text { Advantage to } \\
\text { Timothy (\%) }\end{array}$} \\
\hline & Ryegrass & Timothy & SED & $P$ value & \\
\hline Average no. cows/grazing & 19.6 & 21.3 & 0.07 & 0.02 & 8.6 \\
\hline Stocking rate (cows/ha) ${ }^{1}$ & 3.73 & 4.05 & 2 & - & 8.6 \\
\hline MS yield (kg/cow/day) & 1.19 & 1.43 & 0.02 & $<0.001$ & 20.2 \\
\hline MS yield (kg/ha/day) & 4.43 & 5.79 & - & - & 30.6 \\
\hline
\end{tabular}

the next area to be grazed for each pasture type. These samples were frozen, freeze-dried, and each replicate bulked and analysed for alkane content.

\section{Results}

\section{Experiments 1 \& 2}

A summary of dairy cow performance for experiments 1 and 2 is presented in Table 1 . In spring cows grazing timothy produced more milk $(\mathrm{P}<0.10)$ with similar composition to cows grazing ryegrass. The yield of protein, MS and casein was greater $(\mathrm{P}<0.10)$ from cows grazing timothy than cows grazing ryegrass pasture. In autumn the reverse occurred. The cows grazing ryegrass produced more milk $(\mathrm{P}<0.05)$. There was no effect of pasture type on milk composition or yield of milk fat, protein, and MS but the yield of casein and lactose was greater from ry egrass than timothy. Pasture type had no effect on either live weight or BCS change in Experiment 1 and 2.

In spring the timothy pasture had a higher $(\mathrm{P}<0.05)$ $\mathrm{CP}$ content and WSS $(\mathrm{P}<0.10)$ than ryegrass and was similar in content of ADF, NDF, OMD and ME to ryegrass (Table 2). In autumn, Timothy had higher $(\mathrm{P}<0.0 .05)$ ADF and NDF and lower $(\mathrm{P}<0.10)$ WSS content than ryegrass. Again no difference between ryegrass and timothy pasture in OMD or ME was found.

Herbage mass and intake data collected in Experiment 1 and intake data for experiment 2 are presented in Table 3 . There was no difference between pre and post grazing herbage mass and pasture intake calculated by difference (Hodgson, 1979). Pasture intake assessed by the alkane method in Experiments 1 and 2 was greater $(\mathrm{P}<0.01$,
Experiment 1 and $\mathrm{P}<0.05$, Experiment 2) on timothy than ryegrass. A marked difference between ryegrass and timothy was noted in the composition of the alkanes used to derive intake. For example in Experiment 1 the content (mg alkane/100g DM) of C:31, C:32, and C:33 was 23.0, 1.7 and 15.0 respectively for ryegrass and 4.6, 0.7 and 1.4 respectively for timothy. These differences in alkane content between pasture type were similar in Experiment 2.

\section{Experiment 3}

Cows grazing irrigated timothy pasture during summer/ autumn had increased $(\mathrm{P}<0.001)$ milk yield and yield of milk fat, protein, MS, casein and lactose compared to those grazing irrigated ryegrass pasture (Table 1). Pasture species had no effect on milk fat, protein and casein concentration but lactose concentration was greater $(\mathrm{P}<0.05)$ in milk from cows grazing timothy compared to ryegrass. Cow live weight or liveweight gain was not influenced by pasture species, however, cows grazing timothy pasture had a higher $(\mathrm{P}<0.01)$ BCS.

Timothy pasture during summer and autumn was lower in NDF $(\mathrm{P}<0.01)$ and ADF $(\mathrm{P}<0.10)$ than ryegrass pasture (Table 2 ). The WSS and $\mathrm{CP}$ contents $(\mathrm{P}<0.01$ and $\mathrm{P}<0.10$ for WSS and $\mathrm{CP}$ respectively) of timothy were higher than ryegrass.

The average botanical composition of all paddocks (Table 4) for timothy pastures was 52\% timothy, 20\% white clover and $18 \%$ other grasses (mainly hybrid ryegrass $L$. boucheanum syn $L$. hybridium) whereas the ryegrass pastures had $81 \%$ ryegrass, $2.5 \%$ white clover and $6 \%$ other grasses. The older established block of 
timothy/white clover had a greater proportion of timothy $(65 \%)$ compared with the newer established block $(41 \%)$.

The "put and take" criteria for managing the two pastures resulted in more $(\mathrm{P}<0.05)$ cows being grazed on timothy than ryegrass pasture (Table 5). Timothy pastures were higher yielding, pre-grazing $(\mathrm{P}<0.10)$, had a lower herbage allowance $(\mathrm{P}<0.10)$ and were grazed out harder $(\mathrm{P}<0.01)$ than ryegrass pasture. Cow intake calculated from the alkane method (Table 3) showed that cows grazing ryegrass consumed more $(\mathrm{P}<0.05)$ pasture $\mathrm{DM}$ than cows grazing timothy. This observation was however not confirmed by a calculation of rate of DM disappearance (Hodgson 1979). Intake calculated by the difference method showed that cows grazing timothy/white clover consumed more pasture than cows grazing ryegrass. The stocking rate and MS production per cow was higher on timothy pasture and as a result the difference in MS production/ha favoured timothy over ryegrass pasture by $30 \%$ (Table 5 ).

\section{Discussion}

In two of the three experiments, greater MS production was recorded from the timothy/white clover compared with the ryegrass pastures. However, the herbage dissection data recorded in Experiment 3 showed that the "old" timothy block that was used for experiments 1 and 2 and in part for experiment 3 , contained more white clover than the ryegrass pastures (Table 4). It is well known that animal production $/ \mathrm{kg}$ DM consumed is greater from white clover than ryegrass (Rogers et al. 1982; Thomson 1984; Johnston \& Thomson 1996; Harris et al. 1997). From that alone it would be expected that animal production from timothy/white clover would have been greater than ryegrass. Harris et al. (1997) reported a relationship $\left(\mathrm{R}^{2}=0.48, \mathrm{RSD}=1.43\right)$ between the proportion of white clover in pasture and milk production. From this relationship it was determined that a white clover content of $16 \%$ (average of the timothy/white clover on the "old" block) would result in a $13 \%$ increase in milk yield compared to ryegrass with only $2.6 \%$ white clover. The increase in milk yield in Experiment 3 was $18.6 \%$, which suggests that the greater MS production from timothy/white clover pastures was partly due to timothy sustaining a higher white clover content than ryegrass and partly due to a "timothy" effect.

Increased MS production as a result of grazing timothy pasture has been observed in other studies. Johnston \& Thomson (1996) reported similar levels of MS production from pure swards of timothy and white clover, and MS production from both species was superior to that produced from ryegrass. During one dairying season, seven trials were conducted on the
TARS (Johnston unpublished data) and the average advantage of white clover over ryegrass was $0.11 \mathrm{~kg}$ $\mathrm{MS} /$ cow/day and timothy over ryegrass, $0.09 \mathrm{~kg} \mathrm{MS} /$ cow/day. Lewis \& Cullen (1964) reported lamb growth post-weaning was greater on timothy/cocksfoot than ryegrass pastures and concluded the effect was due to the timothy/cocksfoot pastures sustaining a higher white clover content than ryegrass. However, in a later study (Lewis \& Cullen 1972), the composition of white clover in the two pasture types was balanced and they again found lamb liveweight gain post-weaning was greater from timothy/cocksfoot than ryegrass pastures. From these trials it was apparent that timothy may have quality attributes that are superior to ryegrass.

Johnston \& Thomson (1996) report that timothy and white clover had similar contents of total nitrogen and similar digestibilities to ryegrass. Rode \& Pringle (1986) observed that differences in DM availability or digestibility did not explain the higher live weight gain from steers grazing timothy compared to meadow foxtail (Alopecurus pratensis). In our study the nutritive value of ryegrass and timothy/white clover differed depending on trial and time of year. In general, the beneficial effect of pasture type on MS production reflected the differences in nutritive composition of the pasture. Experiment 2 was conducted after a summer dry spell and the nutritive composition of the pastures showed that timothy/white clover was poorer quality than ryegrass. The indication from these results was that under moisture stress, the nutritive quality of timothy had deteriorated more than ryegrass. Alternatively, as the reproductive stage for timothy is much later than ryegrass (Havstad \& Aamlid 2001), it would be expected that nutritive quality of timothy would be lower (Lindberg \& Lindgreen 1988) than ryegrass during summer in Experiment 2. In Experiment 3, with irrigation during summer and autumn, timothy/white clover contained more protein and WSS and less NDF than ryegrass. The greater MS production from timothy/ white clover pastures in Experiments 1 and 3 may also be due to the higher quality (greater protein and WSS and lower NDF and ADF contents) compared to ryegrass pasture. Although, no difference in digestibility or ME was noted in any experiment and this is in agreement with Johnston \& Thomson (1996) and Rode \& Pringle (1986).

In Experiment 3, the timothy/white clover pastures carried a $9 \%$ higher stocking rate, produced $20 \%$ more $\mathrm{MS} / \mathrm{cow} /$ day and produced $30 \%$ more $\mathrm{MS} / \mathrm{ha}$ than ryegrass pasture. Dry matter production calculated from the average pre- minus post-grazing herbage mass recorded in Experiment 3 was 20\% greater for timothy/ white clover than ryegrass. From this discussion it appears that the greater MS production was due to a 
number of factors; the greater proportion of white clover, the higher "feed quality" of timothy and greater pasture DM production.

The herbage mass estimates in this study should be treated with caution because the plate meter readings were converted to herbage mass using calibration equations established for ryegrass pasture. In the same vein, it could also be argued that the difference in stocking rate reported between the two treatments in Experiment 3 was created by a bias in herbage mass estimates and was not an effect of greater pasture DM production of the timothy/white clover pasture. Every effort was made to maintain similar levels of herbage allowance and residual herbage mass between the two pastures. This was achieved in Experiment 1 but in Experiment 3, cows grazing the timothy/white clover pasture were offered a lower pasture allowance and they grazed the timothy/ white clover pasture lower than ryegrass. The timothy/ white clover pastures were more open and contained more clover than the older ryegrass pastures, which suggests they could have been grazed to a lower herbage mass without adversely affecting pasture intake. Pasture intakes assessed by the alkane method were inconsistent between the three experiments. Compared with ryegrass, cows grazing timothy/white clover had a higher intake in Experiments 1 and 2 and a lower intake in Experiment 3. However, MS production/cow/day did not align well with differenced in pasture intakes as assessed by the alkane method. Pasture intakes assessed by the difference method aligned better with animal performance than those assessed by the alkane method. The low alkane content of timothy/white clover compared to ryegrass may have influenced the accuracy of intake assessment by the alkane method. From these observations, the authors are confident that the greater stocking rate on timothy/white clover was a real effect.

The persistency of timothy and the susceptability to ASW was not investigated in this study but during the periods of investigation in the TARS and our study the pure timothy and the timothy/white clover pastures adequatly survived the two-three year study periods. We suggest that timothy sown as a pure sward or with white clover only may be more persistent than when sown with mixed grass species. To improve the adaptability of timothy to wider dairying regions and to achieve greater persistency, the possibility of incorporating an endophyte into timothy to give resistance to ASW should be investigated.

\section{Conclusion}

From these experiments we conclude that irrigated timothy/white clover pastures will maintain higher levels of MS production than irrigated ryegrass pastures. This is in part due to greater nutritive value (more MS produced/kg DM consumed) and greater pasture DM production. Observations made during this series of experiments suggests that timothy will sustain a higher content of white clover than ryegrass and such a pasture will be productive, of high feed quality and will produce a higher level of animal production than ryegrass alone. From these results we recommend for increasing MS, that timothy/white clover pastures be established into irrigated and summer wet dairying systems.

\section{ACKNOWLEDGEMENTS}

Barbara Dow for statistical analysis, Margaret Bryant for routine milk analysis, Pat Laboyrie for herd management and the farm staff at Dexcel No. 5 Dairy for herd welfare, live weight and BCS recording and milk sampling. The Foundation for Research Science and Technology for funding this research.

\section{REFERENCES}

Barbano, D.M.; Lynch, J.M.; Flemming, J.R. 1991. Direct and indirect determinations of true protein content of milk by Kjeldahl analysis: collaborative study. AOAC 74: 281-288.

Barker, G.M. 1989. Grass host preferences of Listronotus bonariensis(Coleoptera: Curculionidae) Journal of Economic Entomology 82: 1807-1816.

Caradus, J.R. 1988. Performance of six timothy (Phleum pratense L.) lines in pure swards under grazing. New Zealand Journal of Experimental Agriculture 16: 109-112.

Dove, H.; Mayes, R.W. 1991. The use of plant wax alkanes as marker substances in studies of the nutrition of herbivores. A Review. Australian Journal of Agricultural Research 42: 177-184.

Harris, S.L.; Clark, D.A.; Auldist, M.J.; Waugh, C.D.; Laboyrie, P.G. 1997. Optimum white clover content for dairy pastures. Proceedings of the New Zealand Grassland Association 59: 29-33.

Havstad, L.T.; Aamlid, T.S. 2001. Use of regrowth of forage in crops of timothy (Phleum pratense L.) $\mathrm{cv}$. Grindstad for seed in Norway. Grass and Forage Science 57: 147-156.

Hodgson, J. 1979. Nomenclature and definitions in grazing studies. Grass and Forage Science 34: 1118.

International Dairy Federation. 1987. Milk: Determination of fat content - Roëse Gottlieb gravimetric method (reference method). IDF Standard FIL-IDF IC:1987. International dairy Federation, Brussels, Belgium.

Johnston, R.J.; Thomson, N.A. 1996. Effect of pasture species on milk yield and composition. Proceedings of the New Zealand Grassland Association 57: 151- 
156.

Lewis, K.H.C.; Cullen, N.A. 1964. Lamb weight gains on ryegrass and timothy-cocksfoot pastures. New Zealand Journal of Agriculture 198: 537-540.

Lewis, K.H.C.; Cullen, N.A. 1972. Lamb growth on "long" and "short" grazed pastures of ryegrass or timothy/cocksfoot. Proceedings of the New Zealand Grassland Association 34(2): 199-204.

Lindberg, J.E.; Lindgreen, E. 1988. Influence of cutting time and $\mathrm{N}$ fertilisation on the nutritive value of timothy. Swedish Journal of Agricultural Research 18: 91-98.

Maunsell, L.A.; Scott, D. 1996. Timothy cultivars in a New Zealand high country environment. Proceedings of the New Zealand Grassland Association 58: 167170.

Rode, L.M.; Pringle, W.L. 1986. Growth, digestibility, and voluntary intake by yearling steers grazing timothy (Phleum pratense) or meadow foxtail (Alopecurus pratensis) pastures. Canadian Journal of Animal Science 66: 463-472.

Rogers, G.L.; Porter, R.H.D.; Robinson, I. 1982. Comparison of perennial ryegrass and white clover for milk production. pp. 213-214. In: Dairy Production from Pasture. Eds. Macmillan, K.L.; Taufa, V.K. Proceedings of New Zealand and Australian Societies of Animal Production.

Scott, D.; Maunsell, L.A. 1981. Pasture irrigation in the Mackenzie basin 1. Species comparison. New Zealand Journal of Experimental Agriculture 9: 279-290.

Thom, E.R.; Clark, D.A.; Waugh, C.D. 1999. Growth persistence, and alkaloid levels of endophyte-infected and endophyte-free ryegrass pastures grazed by dairy cows in northern New Zealand. New Zealand Journal of Agricultural Research 42: 241-253.

Thom, E.R.; Burggraaf, V.T.; Waugh, C.D.; Clark, D.A. 2001. Effects of pasture species and irrigation on milk production over four summers in the Waikato. Proceedings of the New Zealand Grassland Association 63: 215-221.

Thomson,D.J. 1984. The nutritive value of white clover. pp. 587-598. In: Forage Legumes. Ed. Thomas, D.J.. Occasional Symposium of the British Grassland Society 16.

Thomson, N.A.; Upsdell, M.P.; Hooper, R.; Henderson, H.V.; Blackwell, M.B.; McCallum, D.A.; Hainsworth, R.J.; Macdonald, K.A.; Wildermoth, D.D.; BishopHurley, G.J.; Penno, J.W. 2001. Development and evaluation of a standard means for estimating herbage mass in dairy pastures using the rising plate meter. Proceedings of the New Zealand Grassland Association 63: 149-157. 